\title{
$\beta$-Amyloid Stimulates Murine Postnatal and Adult Microglia Cultures in a Unique Manner
}

\author{
Angela M. Floden and Colin K. Combs \\ Department of Pharmacology, Physiology, and Therapeutics, School of Medicine and Health Sciences, University of North Dakota, Grand Forks, North \\ Dakota 58202
}

\begin{abstract}
Reactive microglia are commonly observed in association with the $\beta$-amyloid $(\mathrm{A} \beta)$ plaques of Alzheimer's disease brains. This localization supports the hypothesis that $\mathrm{A} \beta$ is a specific activating stimulus for microglia. A variety of in vitro studies have used postnatal derived rodent microglia cultures to characterize the ability of $\mathrm{A} \beta$ to stimulate these cells. However, it is unclear whether this paradigm accurately models conditions in aged animals. To determine whether $\mathrm{A} \beta$ stimulatory phenotypes differ between young and adult microglia, we established cultures of acutely isolated adult murine cortical microglia to compare with postnatal derived microglial cultures. Although cells from both ages expressed robust immunoreactivity for CD68 and CD11b, their responses to activating stimuli differed. Fibrillar $\mathrm{A} \beta$ was rapidly phagocytosed by postnatal microglia and both oligomeric and fibrillar peptide stimulated increased tumor necrosis factor $\alpha$ (TNF $\alpha$ ) secretion. However, A $\beta$ oligomers but not fibrils stimulated TNF $\alpha$ secretion from adult microglia. More importantly, adult microglia had diminished ability to phagocytose $\mathrm{A} \beta$ fibrils. These findings demonstrate that adult microglia respond to $A \beta$ fibril stimulation uniquely from postnatal cells and suggest that adult rather than postnatal microglia cultures are more appropriate for modeling proinflammatory changes in the aged CNS.
\end{abstract}

Key words: microglia; tumor necrosis factor; $\mathrm{A} \beta$ peptide; amyloid; neuroinflammation; Alzheimer

\section{Introduction}

The senile plaques in Alzheimer's disease (AD) brains contain fibrillar $A \beta$ peptides and are surrounded by activated microglia (Itagaki et al., 1989; Cotman et al., 1996). These observations support the hypothesis that microglia are stimulated to acquire a reactive phenotype in response to interaction with $\mathrm{A} \beta$ fibrils (Akiyama et al., 2000). A plethora of consequences of amyloidmediated microglial activation has been characterized in vitro including increased secretion of proinflammatory products such as reactive oxygen species, cytokines, and neurotoxins. (Giulian et al., 1995; Meda et al., 1995; Tan et al., 2000; Combs et al., 2001; Xie et al., 2002). Collectively, data such as these support the hypothesis that $\mathrm{A} \beta$-stimulated microglial activation contributes to the pathophysiology of AD. Not surprisingly, strategies to limit the $A \beta$-microglial response are of therapeutic interest.

However, many in vitro studies are performed using microglia derived from brains of postnatal rodents. Microglial preparation from postnatal rodent brains is a reliable, established method that yields a cell population well characterized in the literature (Giulian and Baker, 1986). These cells are taken from the postnatal brain during the period of active microglial proliferation in vivo

\footnotetext{
Received Nov. 9, 2005; revised March 6, 2006; accepted March 29, 2006.

This work was supported by National Institutes of Health-National Center for Research Resources Grant 1 P20 RR17699-01. We are grateful to Dr. M. Carson for helpful discussion and advice.

Correspondence should be addressed to Dr. Colin K. Combs, Department of Pharmacology, Physiology, and Therapeutics, School of Medicine and Health Sciences, University of North Dakota, 504 Hamline Street, Neuroscience Building, Grand Forks, ND 58202. E-mail: ccombs@medicine.nodak.edu.

D01:10.1523/JNEUROSCI.4822-05.2006

Copyright $\odot 2006$ Society for Neuroscience $\quad$ 0270-6474/06/264644-05\$15.00/0
}

(Dalmau et al., 2003) and grow as a loosely adherent cell population atop a bed of mixed glia over several weeks in culture. After isolation from the mixed glial population, a nearly pure culture of microglia is obtained. However, these purified cells are somewhat reactive in culture in comparison with in vivo adult microglia based on morphology and increased immunoreactivity for a host of microglial marker proteins (Carson et al., 1998; Nimmerjahn et al., 2005). This discrepancy suggests that the microglial response to $\mathrm{A} \beta$ derived from postnatal culture studies may differ significantly from that used by adult or aged microglia. In fact, in aged humans and rodents, it has been demonstrated that microglia undergo a morphologic dystrophy characterized by enlargement, deramification, and adoption of a more phagocytic phenotype (Sheng et al., 1998; Streit et al., 2004). These differences suggest that microglial cultures from aged brains may offer a more relevant model system for determining cellular responses to $\mathrm{A} \beta$ stimulation during disease. Importantly, adult microglia culture protocols demonstrate that acutely isolated cells retain a quiescent in vivo phenotype, although increased culture time results in a more reactive phenotype (Becher and Antel, 1996; Slepko and Levi, 1996; De Groot et al., 2000; Frank et al., 2005; Ponomarev et al., 2005).

Based on the previous work demonstrating the feasibility of adult microglia preparations, we sought to determine whether the $\mathrm{A} \beta$ stimulatory response we had previously characterized from postnatal derived microglia was similar to that induced in adult cells (Floden et al., 2005). To minimize phenotype conversion of the microglia induced by prolonged culturing, we chose to use cells acutely isolated from the adult mouse brain. 

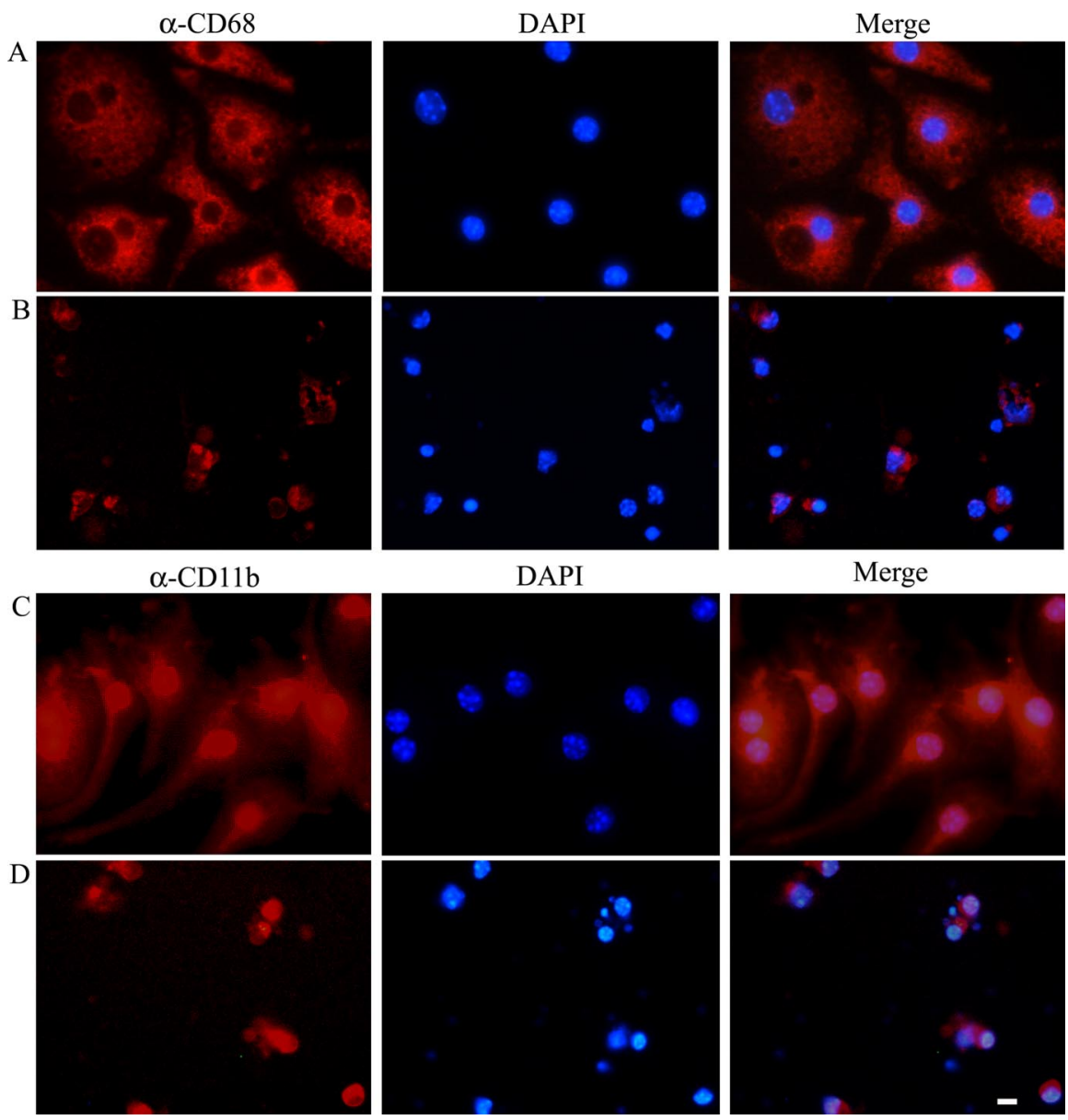

Figure 1. Adult and postnatal brain-derived mouse microglia cultures display similar cell surface marker immunoreactivity Cultures of postnatal-derived microglia were collected from mixed glial cultures at $14 \mathrm{~d}$ in vitro and plated onto glass chamberslides for $24 \mathrm{~h}$. Adult microglia were isolated from brains and plated for $24 \mathrm{~h}$ in vitro. Cells were fixed with $4 \%$ paraformaldehyde and immunostained using anti-CD68 $(\boldsymbol{A}, \boldsymbol{B})$ or - $\operatorname{CD11b}(\boldsymbol{C}, \boldsymbol{D})$ antibodies. Antibody binding was visualized using Texas Redconjugated secondary antibody, and cellular nuclei were counterstained with DAPI for imaging. Scale bar, $20 \mu \mathrm{m}$.
A $\beta 1-42$ (FITC-A $\beta$; rpeptide, Athens, GA) was used to prepare fluorescent aggregates for the phagocytosis assays according to the manufacturer's instructions. All peptides were resolved via SDS-PAGE and Western blotted to confirm an oligomeric (dimer/trimer) or fibrillar conformation before use. All peptide stimulations were performed using the same purchased lot and preparations of peptide conformations for both adult and postnatal cultures to insure an accurate comparison between cell ages.

Quantitation of secreted tumor necrosis factor $\alpha$. After $24 \mathrm{~h}$ stimulation, $70 \mu \mathrm{l}$ of media was removed from the individual culture wells for tumor necrosis factor $\alpha$ (TNF $\alpha$ ) quantitation. Concentrations of secreted TNF $\alpha$ were then determined using commercially available mouse TNF $\alpha$ colorimetric sandwich ELISA plates (R \& D Systems, Minneapolis, MN).

Phagocytosis assay. Peptide phagocytosis was quantitated by measuring the uptake of FITClabeled $\mathrm{A} \beta 1-42$. Briefly, $\mathrm{A} \beta$ aggregates (500 $\mathrm{nM}$ ) or FITC-E. coli bioparticles (positive control, $0.25 \mathrm{mg} / \mathrm{ml}$ ) were incubated with the microglia in 96-well plates for $6 \mathrm{~h}$. To quench the signal from extracellular peptide, medium was removed and the cells were rinsed with 0.25 $\mathrm{mg} / \mathrm{ml}$ trypan blue in PBS. Application of trypan serves to quench any remaining peptide on the plate as well as any bound to the external leaflet of the plasmalemma. Intracellular fluorescence was read (480 $\mathrm{nm}$ excitation and 520 $\mathrm{nm}$ emission) via fluorescent plate reader (BioTek, Winooski, VT).

Cell viability assay. To determine cell viability after $24 \mathrm{~h}$ stimulation, cellular release of lactate dehydrogenase (LDH) was measured from culture media using a commercial nonradioactive assay (Promega, Madison, WI). Absorbance measurements were taken at $490 \mathrm{~nm}$.

Immunocytochemistry. To perform culture immunocytochemistry, microglia were plated

\section{Materials and Methods}

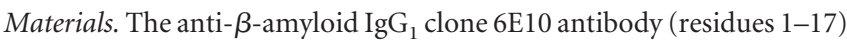
was purchased from Signet Laboratories (Dedham, MA). Anti- $\beta$ amyloid $\operatorname{IgG}_{1}$ clone BAM-10 (residues 1-12), and lipopolysaccharide (LPS) were purchased from Sigma (St. Louis, MO). The CD11b and CD68 antibodies were purchased from Serotec (Raleigh, NC). FITClabeled Escherichia coli (K-12 strain) bioparticles were from Invitrogen (Eugene, OR).

Tissue culture. Microglia were derived from postnatal day 1 (P1) to P3 mouse brains (C57BL/6) as described previously (Floden et al., 2005). Postnatal microglia were isolated from $14 \mathrm{~d}$ in vitro cultures for immediate use. Adult microglia were taken from 5-8 month mouse brains $(\mathrm{C} 57 \mathrm{BL} / 6)$ as previously described and used immediately after isolation (Carson et al., 1998).

Cell stimulation. Adult and postnatal derived microglia were plated onto 96-well tissue culture plates (20,000 cells/well; $75 \mu \mathrm{l}$ of serum-free DMEM/F12) for 6 or $24 \mathrm{~h}$. Cultures were stimulated with fibrillar or oligomeric A $\beta$ peptide or $25 \mathrm{ng} / \mathrm{ml}$ LPS. Experiments were performed with eight replicates per condition, three to four independent times. Data are presented as mean $\pm \mathrm{SD}$. Values statistically different from controls were determined using one-way ANOVA. The Tukey-Kramer multiplecomparison post test was used to determine $p$ values.

Human A $\beta 1-42$ preparation. To generate fibrillar and oligomeric peptides for cell stimulation, $A \beta 1-42$ was purchased from Bachem (Torrance, CA) or American Peptide (Sunnyvale, CA). A $\beta$ oligomers were generated as described by Chromy et al. (2003). Fibrils were generated as described previously (Floden et al., 2005). A FITC conjugate of human on glass chamberslides for $24 \mathrm{~h}$ then fixed in $4 \%$ paraformaldehyde $\left(37^{\circ} \mathrm{C}, 30 \mathrm{~min}\right)$ and immunostained using anti-CD68 and anti-CD11b antibodies using Vector VIP as the chromagen (Vector Laboratories, Burlingame, CA) or Texas Red secondary (Santa Cruz Biotechnology, Santa Cruz, CA) with 4',6'-diamidino-2-phenylindole (DAPI) (Invitrogen) to visualize the nucleus. Microglial purity was determined by placing a counting grid under the wells and counting CD68-positive microglia compared with total hematoxylin (Sigma) nuclear stained cells from four identical fields per well for each condition. The average number of microglia $( \pm S D)$ was calculated for each condition. Each experiment was performed in quadruplicate three to four times.

Animal care and use. All procedures were reviewed and approved by the University of North Dakota Institutional Animal Care and Use Committee (protocol no. 0012-3). Mice were housed at the Center for Biomedical Research on a $12 \mathrm{~h}$ light/dark cycle and were allowed food and water ad libitum. Adult mice were killed via $\mathrm{CO}_{2}$ asphyxiation for collection of brains. Postnatal pups were killed via decapitation.

\section{Results}

Purified adult microglia are morphologically different from postnatally derived microglia

To begin comparing primary adult and postnatal mouse microglia cultures, we first verified culture purity as well as immunoreactivity for two well established microglial markers, CD68 and CD11b (Fig. 1). Postnatal microglia were used directly after isolation from a mixed glial bed at $14 \mathrm{~d}$ in vitro, whereas the adult 
microglia were used immediately after isolation from the brain. Although both cell types were immunoreactive for CD11b and CD68, the postnatal cells displayed a dramatically different morphology than adult cells (Fig. 1). Postnatal cells demonstrated a larger diameter, flattened phenotype in comparison with adult microglia. Importantly, both culture types were of similar purity based on percent CD68 immunoreactivity ( $\geq 99 \%$ for postnatal cells and $\geq 97 \%$ for adult cells) (data not shown). These data verified our system for subsequent analysis.

\section{Fibrillar A $\beta$ stimulates TNF $\alpha$ secretion only from postnatal microglia}

Because proinflammatory cytokines such as TNF $\alpha$ are associated with plaques in AD (McGeer and McGeer, 1995), and previous data have demonstrated that $\mathrm{A} \beta$ fibrils stimulate microglial TNF $\alpha$ secretion in vitro (Meda et al., 1995; Tan et al., 2000; Floden et al., 2005), we compared the ability of $A \beta$ fibrils to stimulate TNF $\alpha$ secretion from postnatal versus adult microglia. Prior data have demonstrated that the oligomeric form of $A \beta$ is also a potent microglia stimulus, suggesting that either conformation can contribute to the reactive microgliosis observed in $\mathrm{AD}$ (Roher et al., 1996). Therefore, we also compared the ability of oligomeric A $\beta$ to stimulate the cells. We stimulated both cell types with increasing concentrations of either peptide for $24 \mathrm{~h}$. The cells were stimulated for only $24 \mathrm{~h}$ to minimize the probability that any secretory changes resulted from secondary, autocrine stimulation of the cells. Although the peptides appeared toxic at highest concentrations, both $\mathrm{A} \beta$ oligomers and fibrils stimulated a dosedependent, significant increase in $\mathrm{TNF} \alpha$ secretion from postnatal cells (Fig. 2A). Conversely, adult cells responded in a different manner to peptide stimulation. Oligomeric peptides stimulated TNF $\alpha$ secretion from adult cells in a dose-dependent manner, whereas fibrils had no effect on cytokine secretion (Fig. 3A).

\section{Adult microglia have reduced ability to phagocytose $\mathrm{A} \beta$ in vitro}

We next determined whether adult and postnatal microglia differed in their ability to phagocytose A $\beta$ fibrils. Significant amyloid uptake was observed in postnatal cells after $6 \mathrm{~h}$ of stimulation and was increased after opsonization with two different anti-A $\beta$ antibodies (Fig. $4 A$ ). In contrast, adult microglia were unable to take up $\mathrm{A} \beta$ fibrils regardless of antibody opsonization (Fig. $4 A$ ). However, adult microglia phagocytosed E. coli bioparticles demonstrating specificity for the diminished $\mathrm{A} \beta$ response (Fig. $4 \mathrm{~B}$ ). A modest increase in $A \beta$ uptake was observed in adult cells after opsonization and a $24 \mathrm{~h}$ incubation demonstrating some limited ability for adult microglia to take up the peptide (data not shown).

\section{Discussion}

In this study, we demonstrate that microglia acutely isolated from adult mouse brain differ dramatically in their response to $\mathrm{A} \beta$ fibril stimulation when compared with microglia from standard postnatal brain culture preparations (Giulian and Baker, 1986). This is not surprising given the fact that microglia in aged human and rodent brains undergo morphologic dystrophy characterized by enlargement, deramification, and adoption of a more phagocytic phenotype (Sheng et al., 1998; Streit et al., 2004). More importantly, studies using both human and rodent adult microglial cultures have demonstrated that adult cells respond differently than postnatal cells regarding upregulation of cyclooxygenase expression (Hoozemans et al., 2002) and interleukin 6 (IL-6) and IL- $1 \beta$ secretion (Xie et al., 2003) after stimulation with $\mathrm{A} \beta$
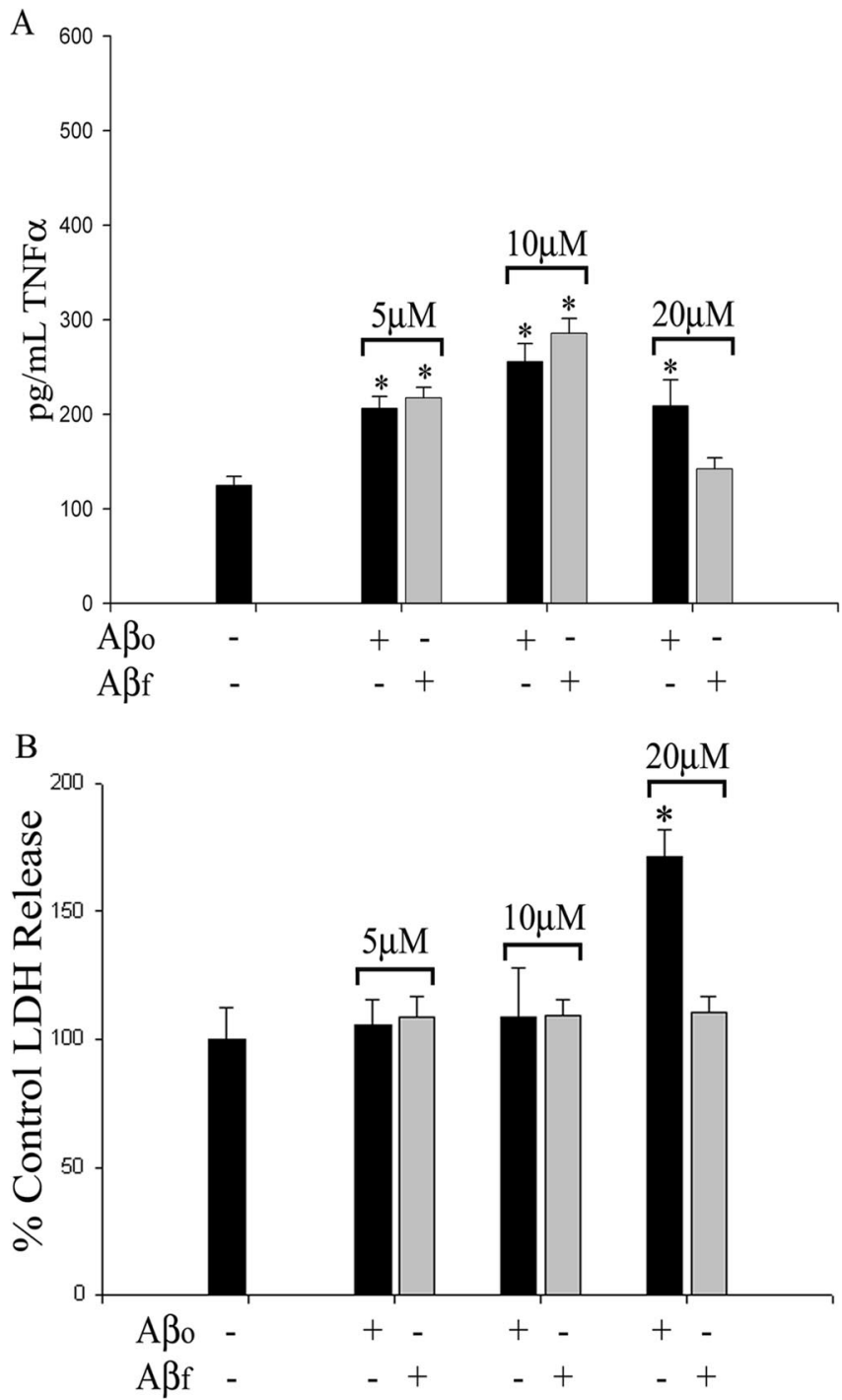

Figure 2. Postnatal brain-derived microglia secrete TNF $\alpha$ after stimulation with fibrillar and oligomeric $A \beta 1-42$ peptide. Postnatal microglia isolated from $14 \mathrm{~d}$ in vitro mixed glial cultures were stimulated $24 \mathrm{~h}$ in the absence or presence of 5,10 , and $20 \mu \mathrm{m}$ oligomeric $A \beta 1-42\left(A \beta_{0}\right)$ or fibrillar $A \beta 1-42\left(A \beta_{f}\right) . A$, Conditioned media was collected from stimulated cells, and TNF $\alpha$ concentrations were determined via commercial ELISA. $\boldsymbol{B}$, Cell viability after $24 \mathrm{~h}$ stimulation was determined by quantitating LDH release into the media using a commercial assay. Graphs are representative of three independent experiments \pm SD $\left({ }^{*} p<0.001\right.$ from respective control).

(Hoozemans et al., 2002) and LPS (Xie et al., 2003). In contrast to these studies, we used adult microglia acutely isolated from the brain rather than implementing a prolonged culture protocol, because it is known that this stimulates conversion to an active phenotype (Becher and Antel, 1996; Slepko and Levi, 1996). It is important to point out that we cannot rule out the possibility that the phenotype of the adult cells is altered during the isolation procedure and not precisely reflective of in vivo phenotype. However, the adult cells clearly respond to oligomeric peptide stimulation and phagocytose E. coli bioparticles indicating that they are not fundamentally compromised. As already mentioned, we have not allowed a recovery period before stimulation, because prolonged culturing leads to a histological phenotype similar to that observed in postnatal cultures (data not shown), subsequent activation and therefore conditions even further removed from in vivo. 

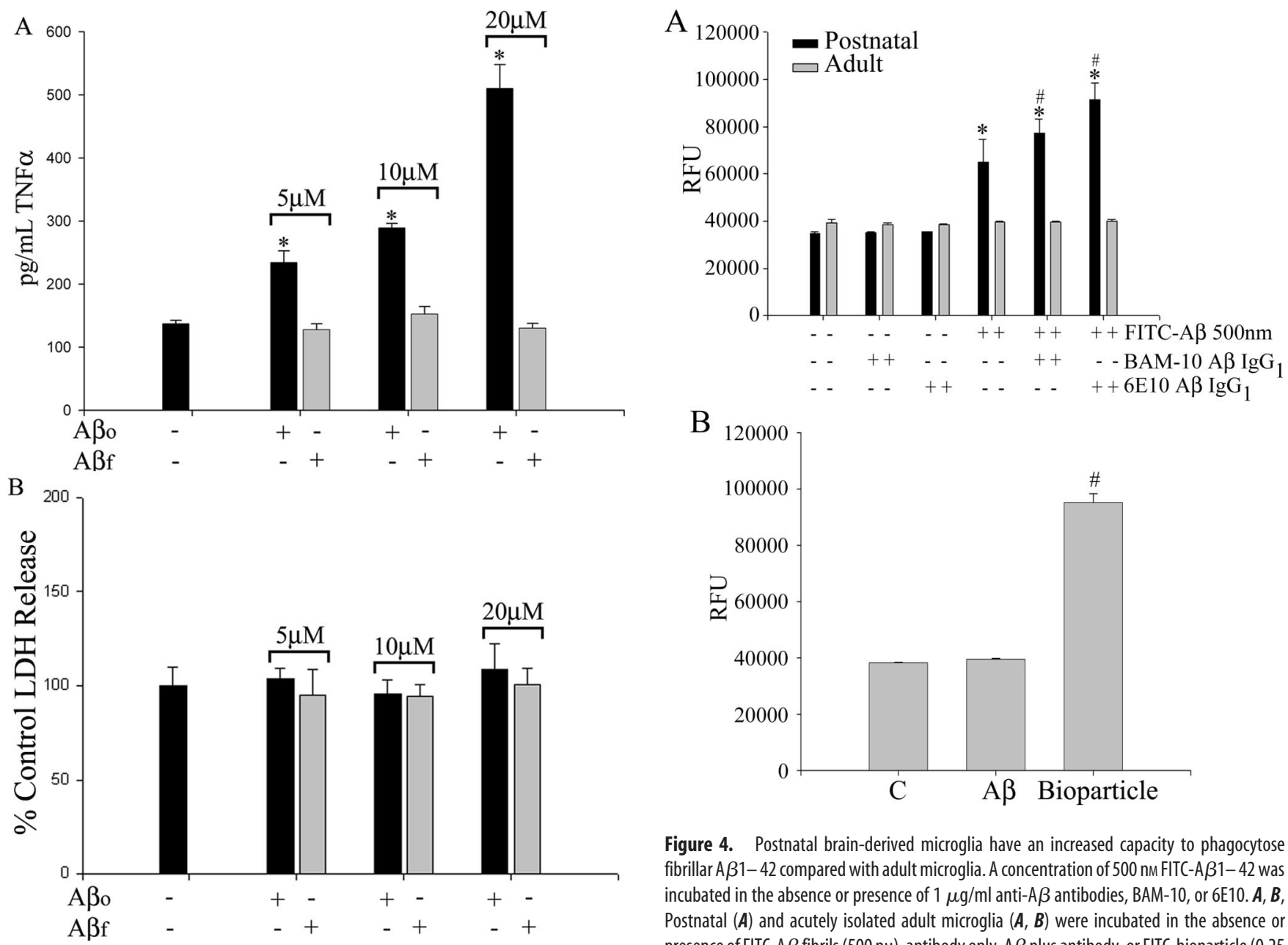

Figure 4. Postnatal brain-derived microglia have an increased capacity to phagocytose fibrillar $A \beta 1-42$ compared with adult microglia. A concentration of $500 \mathrm{~nm}$ FITC-A $\beta 1-42$ was incubated in the absence or presence of $1 \mu \mathrm{g} / \mathrm{ml}$ anti-A $\beta$ antibodies, BAM-10, or 6E10. $A, B$, Postnatal $(\boldsymbol{A})$ and acutely isolated adult microglia $(\boldsymbol{A}, \boldsymbol{B})$ were incubated in the absence or presence of FITC-A $\beta$ fibrils $(500 \mathrm{~nm})$, antibody only, $A \beta$ plus antibody, or FITC-bioparticle $(0.25$ $\mathrm{mg} / \mathrm{ml}$; positive control) for $6 \mathrm{~h}$. After incubation, the medium was removed and the signal from unphagocytosed peptide was quenched with trypan blue. Fluorescence intensity from phagocytosed peptide in each condition was quantitated using a fluorescent plate reader $(480 \mathrm{~nm}$ excitation and $520 \mathrm{~nm}$ emission) and averaged ( \pm SD). Graphs are representative of three independent experiments ( ${ }^{*} p<0.05 ;{ }^{\#} p<0.001$ from respective control).

$\left(A \beta_{f}\right)$. A TNF $\alpha$ concentrations were quantitated from media a liquots from stimulated commercial ELISA. B, Cell viability after the stimulation was assessed by quantitating LDH release into the media using a commercial assay. Graphs are representative of three independent experiments \pm SD $\left({ }^{*} p<0.001\right.$ from respective control).

In addition to the histological differences between ages, we also observed a significant difference in stimulated secretion between the two cell types. Postnatal cultures secreted TNF $\alpha$ in response to stimulation with both $\mathrm{A} \beta$ fibrils and oligomers, whereas adult cultures increased cytokine secretion only after oligomeric peptide stimulation. Although fibril-stimulated secretion is in agreement with our previous work as well as that of others performed using postnatal derived microglia (Meda et al., 1995; Tan et al., 2000; Floden et al., 2005), our data from the adult microglia suggests that postnatal cells may not represent the most accurate experimental model for adult or aged paradigms. Interestingly, our results suggest that oligomeric peptide serves as a proinflammatory ligand independent of animal age, perhaps supporting the hypothesis that this peptide conformation represents the more relevant disease entity mediating cell death and dysfunction (Selkoe, 2002).

The difference in ability to phagocytose $A \beta$ was another unexpected observation between culture ages. Although postnatal cells effectively phagocytosed $\mathrm{A} \beta$ fibrils with and without opsonizing antibodies, adult cells were unable to do this. However, the adult cells efficiently phagocytosed bacterial bioparticles. This

demonstrates that the diminished uptake of $\mathrm{A} \beta$ was not an issue of incomplete recovery from the isolation procedure, but rather, the microglia were truly unable to phagocytose the fibrillar peptide. It is curious that opsonizing antibodies afforded little improvement in adult cell uptake, particularly in light of the in vivo demonstrations of the ability of $\mathrm{A} \beta$ immunization to decrease plaque load (Schenk et al., 1999; DeMattos et al., 2001; Bacskai et al., 2002; Wilcock et al., 2003). It is intriguing to speculate that microglia have reduced capacity to clear $A \beta$ plaques in adult brains, perhaps contributing to the age dependency of plaque deposition observed during disease.

Finally, there is some evidence that microglia from AD brains have phenotypes unique to disease. Lue et al. (2001) have reported that $13-15 \mathrm{~d}$ in vitro cultures of microglia derived from human $\mathrm{AD}$ patients secrete elevated levels of IL- $1 \beta$, TNF $\alpha$, IL- 6 , and MCP-1 (monocyte chemoattractant protein 1) compared with control microglia. Others have demonstrated that peripheral blood-derived macrophages from $\mathrm{AD}$ patients have reduced capacity to phagocytose $A \beta$ compared with cells from agematched controls (Fiala et al., 2005). Together, these data illustrate that adult $\mathrm{AD}$ microglia appear to respond fundamentally different to $A \beta$ stimulation compared with control cells and complement our observations of differences between aged and 
postnatal cells. Although still in vitro, our results suggest that studies performed using microglial cultures from aged or diseased brains offer a more relevant understanding of microglial responses to $\mathrm{A} \beta$ stimulation and phagocytosis.

\section{References}

Akiyama H, Barger S, Barnum S, Bradt B, Bauer J, Cole GM, Cooper NR, Eikelenboom P, Emmerling M, Fiebich BL, Finch CE, Frautschy S, Griffin WS, Hampel H, Hull M, Landreth G, Lue L, Mrak R, Mackenzie IR, McGeer PL, et al. (2000) Inflammation and Alzheimer's disease. Neurobiol Aging 21:383-421.

Bacskai BJ, Kajdasz ST, McLellan ME, Games D, Seubert P, Schenk D, Hyman BT (2002) Non-Fc-mediated mechanisms are involved in clearance of amyloid- $\beta$ in vivo by immunotherapy. J Neurosci 22:7873-7878.

Becher B, Antel JP (1996) Comparison of phenotypic and functional properties of immediately ex vivo and cultured human adult microglia. Glia 18:1-10.

Carson MJ, Reilly CR, Sutcliffe JG, Lo D (1998) Mature microglia resemble immature antigen-presenting cells. Glia 22:72-85.

Chromy BA, Nowak RJ, Lambert MP, Viola KL, Chang L, Velasco PT, Jones BW, Fernandez SJ, Lacor PN, Horowitz P, Finch CE, Krafft GA, Klein WL (2003) Self-assembly of Abeta(1-42) into globular neurotoxins. Biochemistry 42:12749-12760.

Combs CK, Karlo JC, Kao SC, Landreth GE (2001) $\beta$-Amyloid stimulation of microglia and monocytes results in $\mathrm{TNF} \alpha$-dependent expression of inducible nitric oxide synthase and neuronal apoptosis. J Neurosci 21:1179-1188.

Cotman CW, Tenner AJ, Cummings B (1996) beta-Amyloid converts an acute phase injury response to chronic injury responses. Neurobiol Aging 17:723-731.

Dalmau I, Vela JM, Gonzalez B, Finsen B, Castellano B (2003) Dynamics of microglia in the developing rat brain. J Comp Neurol 458:144-157.

De Groot CJ, Montagne L, Janssen I, Ravid R, Van Der Valk P, Veerhuis R (2000) Isolation and characterization of adult microglial cells and oligodendrocytes derived from postmortem human brain tissue. Brain Res Brain Res Protoc 5:85-94.

DeMattos RB, Bales KR, Cummins DJ, Dodart JC, Paul SM, Holtzman DM (2001) Peripheral anti-A beta antibody alters CNS and plasma A beta clearance and decreases brain A beta burden in a mouse model of Alzheimer's disease. Proc Natl Acad Sci USA 98:8850-8855.

Fiala M, Lin J, Ringman J, Kermani-Arab V, Tsao G, Patel A, Lossinsky AS, Graves MC, Gustavson A, Sayre J, Sofroni E, Suarez T, Chiappelli F, Bernard G (2005) Ineffective phagocytosis of amyloid-beta by macrophages of Alzheimer's disease patients. J Alzheimers Dis 7:221-232.

Floden AM, Li S, Combs CK (2005) Beta-amyloid-stimulated microglia induce neuron death via synergistic stimulation of tumor necrosis factor $\alpha$ and NMDA receptors. J Neurosci 25:2566-2575.

Frank MG, Wieseler-Frank JL, Watkins LR, Maier SF (2005) Rapid isolation of highly enriched and quiescent microglia from adult rat hippocampus: immunophenotypic and functional characteristics. J Neurosci Methods 151:121-130.

Giulian D, Baker TJ (1986) Characterization of ameboid microglia isolated from developing mammalian brain. J Neurosci 6:2163-2178.

Giulian D, Haverkamp LJ, Li J, Karshin WL, Yu J, Tom D, Li X, Kirkpatrick JB (1995) Senile plaques stimulate microglia to release a neurotoxin found in Alzheimer brain. Neurochem Int 27:119-137.
Hoozemans JJ, Veerhuis R, Janssen I, van Elk EJ, Rozemuller AJ, Eikelenboom $P$ (2002) The role of cyclo-oxygenase 1 and 2 activity in prostaglandin $\mathrm{E}(2)$ secretion by cultured human adult microglia: implications for Alzheimer's disease. Brain Res 951:218-226.

Itagaki S, McGeer PL, Akiyama H, Zhu S, Selkoe D (1989) Relationship of microglia and astrocytes to amyloid deposits of Alzheimer disease. J Neuroimmunol 24:173-182.

Lue LF, Walker DG, Rogers J (2001) Modeling microglial activation in Alzheimer's disease with human postmortem microglial cultures. Neurobiol Aging 22:945-956.

McGeer PL, McGeer EG (1995) The inflammatory response system of brain implications for therapy of Alzheimer and other neurodegenerative diseases. Brain Res Brain Res Rev 21:195-218.

Meda L, Cassatella MA, Szendrei GI, Otvos Jr L, Baron P, Villalba M, Ferrari D, Rossi F (1995) Activation of microglial cells by beta-amyloid protein and interferon-gamma. Nature 374:647-650.

Nimmerjahn A, Kirchhoff F, Helmchen F (2005) Resting microglial cells are highly dynamic surveillants of brain parenchyma in vivo. Science 308:1314-1318.

Ponomarev ED, Novikova M, Maresz K, Shriver LP, Dittel BN (2005) Development of a culture system that supports adult microglial cell proliferation and maintenance in the resting state. J Immunol Methods 300:32-46.

Roher AE, Chaney MO, Kuo YM, Webster SD, Stine WB, Haverkamp LJ, Woods AS, Cotter RJ, Tuohy JM, Krafft GA, Bonnell BS, Emmerling MR (1996) Morphology and toxicity of Abeta-(1-42) dimer derived from neuritic and vascular amyloid deposits of Alzheimer's disease. J Biol Chem 271:20631-20635.

Schenk D, Barbour R, Dunn W, Gordon G, Grajeda H, Guido T, Hu K, Huang J, Johnson-Wood K, Khan K, Kholodenko D, Lee M, Liao Z, Lieberburg I, Motter R, Mutter L, Soriano F, Shopp G, Vasquez N, Vandevert C, et al. (1999) Immunization with amyloid-beta attenuates Alzheimer-diseaselike pathology in the PDAPP mouse. Nature 400:173-177.

Selkoe DJ (2002) Alzheimer's disease is a synaptic failure. Science 298:789-791.

Sheng JG, Mrak RE, Griffin WS (1998) Enlarged and phagocytic, but not primed, interleukin-1 alpha-immunoreactive microglia increase with age in normal human brain. Acta Neuropathol (Berl) 95:229-234.

Slepko N, Levi G (1996) Progressive activation of adult microglial cells in vitro. Glia 16:241-246.

Streit WJ, Sammons NW, Kuhns AJ, Sparks DL (2004) Dystrophic microglia in the aging human brain. Glia 45:208-212.

Tan J, Town T, Mori T, Wu Y, Saxe M, Crawford F, Mullan M (2000) CD45 opposes $\beta$-amyloid peptide-induced microglial activation via inhibition of p44/42 mitogen-activated protein kinase. J Neurosci 20:7587-7594.

Wilcock DM, DiCarlo G, Henderson D, Jackson J, Clarke K, Ugen KE, Gordon MN, Morgan D (2003) Intracranially administered anti-A $\beta$ antibodies reduce $\beta$-amyloid deposition by mechanisms both independent of and associated with microglial activation. J Neurosci 23:3745-3751.

Xie Z, Wei M, Morgan TE, Fabrizio P, Han D, Finch CE, Longo VD (2002) Peroxynitrite mediates neurotoxicity of amyloid $\beta$-peptide $1-42$ - and lipopolysaccharide-activated microglia. J Neurosci 22:3484-3492.

Xie Z, Morgan TE, Rozovsky I, Finch CE (2003) Aging and glial responses to lipopolysaccharide in vitro: greater induction of IL-1 and IL-6, but smaller induction of neurotoxicity. Exp Neurol 182:135-141. 